(C) 2021, The Authors. Published by Elsevier Inc. and Fass Inc. on behalf of the American Dairy Science Association ${ }^{\circledR}$. This is an open access article under the CC BY-NC-ND license (http://creativecommons.org/licenses/by-nc-nd/4.0/).

\title{
Influence of production, reproduction, morphology, and health traits on true and functional longevity in French Holstein cows
}

\author{
R. Rostellato, ${ }^{1 *} \odot$ J. Promp, ${ }^{2}$ H. Leclerc, ${ }^{3} \odot$ S. Mattalia, ${ }^{2}$ N. C. Friggens, ${ }^{4}$ D. Boichard, ${ }^{1} \odot$ and V. Ducrocq ${ }^{1}$ \\ ${ }^{1}$ Université Paris-Saclay, INRAE, AgroParisTech, UMR GABI, 78350 Jouy-en-Josas, France \\ ${ }^{2}$ Institut de l'Elevage, 75595 Paris, France \\ ${ }^{3}$ Allice, 75595 Paris, France \\ ${ }^{4}$ Université Paris Saclay, INRAE, AgroParisTech, UMR Modélisation Systémique Appliquée aux Ruminants (MoSAR), 75005 Paris, France
}

\begin{abstract}
In the long term, resilient animals are able to maintain their normal biological processes when confronted with environmental perturbations, reducing their risk of being culled. Therefore, longevity can be proposed as an indicator of long-term resilience. Decisions to remove a given dairy cow from the herd are mainly related to low milk production (i.e., voluntary culling) or to reasons other than production (i.e., involuntary culling). The aptitude of animals to delay any culling is defined as true longevity (TL), whereas functional longevity (FL) is the ability to avoid involuntary culling. The aim of the study was to investigate the influence of production, reproduction, morphology, and health traits on TL and FL, to identify risk factors for culling. Data included 278,217 lactations from 122,461 Holstein Friesian cows reared in 640 herds. The length of productive life, calculated as the time between first calving and culling, or censoring, was used as the measure of longevity. Survival analysis was performed using proportional hazards models assuming a piecewise Weibull distribution of the baseline hazard function, with or without adjustment for milk production to evaluate FL and TL. Insemination status, calving ease, mastitis, somatic cell count, displaced abomasum, and udder depth had significant relationships with TL and FL. Differences in estimates of relative risk between TL and FL showed that milk production often influenced culling decisions: farmers are more prone to cull animals with low production even when they had good other characteristics. The culling risk factors identified in the present study can be used to study resilience in dairy cattle and to improve genetic evaluations of functional or total longevity.
\end{abstract}

Received November 30, 2020.

Accepted August 9, 2021.

*Corresponding author: roberta.rostellato@inrae.fr
Key words: culling risk, dairy cattle, longevity, resilience, survival analysis

\section{INTRODUCTION}

In the short term, resilience is defined as the capacity of the animals to be minimally affected by disturbances or to rapidly return to a stable initial state after exposure to a disturbance (Berghof et al., 2019). In the longer term, resilient animals are able to maintain their normal productive life when confronted with environmental perturbations (e.g., to grow toward sexual maturity, to survive until the next reproductive opportunity, and to reproduce successfully), reducing the risk of being culled [i.e., postponing both voluntary and involuntary culling (Friggens et al., 2017)]. Thus, longevity reflects the accumulated benefits of good resilience (Poppe et al., 2020) and it can be proposed as an indicator of long-term resilience. However, because longevity is also affected by factors other than animals' innate resilience, the use of longevity as an indicator of long-term resilience requires that these other factors (farm management, local production conditions, and so on) are adjusted for in any such analysis.

For dairy cattle, the most important part of life is the productive period after first calving. Therefore, the most popular measure of longevity is the length of productive life (LPL), defined as the time between the date of the first calving and the date of culling (VanRaden et al., 2006). Decisions to replace dairy cows are mainly related to low milk production (i.e., voluntary culling) or to reasons other than production such as fertility problems or diseases (i.e., involuntary culling). For this reason, 2 different longevity traits are usually defined: true (TL) and functional (FL) longevity. True longevity is the aptitude to delay any culling, whereas FL is the ability to avoid involuntary culling. Given that there is not a direct measure for FL, it can be obtained by including in the statistical analysis of longevity a correction for the probability to be culled due to low milk production (Ducrocq et al., 1988). 
Several studies in the literature investigated the effect of nongenetic factors on longevity in different cattle populations. Milk production traits, stage of lactation, age at first calving, parity, variation in herd size, and geographical region are factors that contribute significantly to culling decisions (Roxström et al., 2003; Ducrocq, 2005). In addition, poor fertility, difficult calvings, poor udder health, and diseases represent risk factors for culling (Beaudeau et al., 2000; Olechnowicz et al., 2016).

Survival analysis was largely applied to study longevity in cattle (Ducrocq, 1994; Beaudeau at al., 1995). It is a statistical methodology for analyzing events, where the outcome variables are a measure of time elapsed from a starting point (here, the date of first calving) until the occurrence of an episode such as culling or death (Lee, 1992; Schneider et al., 2005). When life data are studied, survival analysis has several advantages with respect to other statistical methods. First, it can combine information on alive (censored) and dead (uncensored) individuals, exploiting all available information. Moreover, this method accounts for nonlinear characteristics of longevity data and can accommodate, as time-dependent variables, effects influencing productive life that vary with time (such as milk production).

French dairy cattle have been routinely evaluated for FL since 1997. The current survival analysis model is a Weibull proportional hazard model including several nongenetic factors such as age at first calving, herd size variation, and milk production traits (Ducrocq, 2005). This model aims at estimating the breeding values for FL and therefore must not correct for animal components which could explain individual differences in FL. At present, fertility, morphology, and health data are not taken into account in this model.

With the aim to better understand resilience in French Holstein cattle, the objective of the study was to investigate the influence of several production, reproduction, morphology, and health traits on TL and FL using a Weibull proportional hazard model.

\section{MATERIALS AND METHODS}

\section{Data Editing and Preparation}

Edits of the data set and the preparation of data for survival analysis were performed using $\mathrm{R}$ statistical software version 3.5.0 ( $\mathrm{R}$ Core Team, 2018) and FORTRAN 90.

Data Edits. Data originated from 2 different databases. In France, breeders are required to record in a diary any diseased animal and the medical drugs that they use to treat or prevent a disease. In this study, the data related to diseases were collected from these diaries, as part of the GénoSanté project carried out in Western France (Leclerc et al., 2019). This project aimed at developing selection tools for new health traits. The other data (i.e., identities of cows and herds, calving dates, calving conditions, milk production, SCC, inseminations, mastitis cases, morphology, and culling dates) were obtained from the French bovine national database. Health events may not be exhaustive in some herds because they are recorded by farmers (not veterinarians) and only recording of treatments (not health events) is mandatory. Moreover, until now, there is very limited added value for farmers in these data that would encourage them to better record health events. Therefore, a drastic selection of herds had to be performed for our study, to consider information from herds having a good practice in recording such events. The selection rules were determined using past experiences with the same type of data (Bourrigan et al., 2016): (1) the herds had to have an exhaustive record of health events over at least 5 consecutive years. They had to record a minimum number of 10 health events per year (excluding mastitis which was considered separately, as a specific health trait). (2) Most of their cows had to have spent their whole productive life in the same herd. Using these rules, 640 herds out of a set of 12,661 herds were selected for our study.

The period of completeness of disease recording (CDR) is specific to each herd (between 5 and $10 \mathrm{yr}$ ) and only data recorded during this period were used. Only animals with milk production records for at least the first lactation during the CDR period were selected. In addition, test-day (TD) measurements for fat content, protein content, and SCC were set as missing in the case of abnormal values (fat content lower than $20 \mathrm{~g} / \mathrm{kg}$ or higher than $90 \mathrm{~g} / \mathrm{kg}$, protein content lower than $15 \mathrm{~g} / \mathrm{kg}$ or higher $70 \mathrm{~g} / \mathrm{kg}$, SCC equal to 0 ). After editing, the data set included 278,217 lactations from 122,461 Holstein Friesian cows born between January 2003 and June 2017. Cows were required to have a first calving date between January 2007 and October 2019.

Two separate data sets were constructed for displaced abomasum (DA) and milk fever (MF). For those traits, a specific herd selection was performed, where only herds that declared at least one event of these diseases during the CDR period were considered. Data for DA included 99,768 animals reared in 494 herds, whereas 114,077 cows reared in 588 herds had information on MF.

Computation and Classification of Nongenetic Factors. For the functional longevity models, a correction for milk production traits was included, taking into account the lactation milk yield (milk) as well as 
fat and protein (PROT) contents for a 305-d lactation length. These factors were obviously time dependent (i.e., their values changed from one lactation to the next). Within herd-year combination, an average lactation production was then calculated, separately for first and later lactations, excluding short lactations $(<100$ d). Then, deviations for the standardized individual 305-d lactation productions (DSI 305d_lac) from their corresponding within herd-year average lactation production were calculated and divided by the observed standard deviation of DSI 305d_lac. Finally, separately for first and later lactation, these within herd-year deviations were transformed into milk production classes, with 10 classes of equal size and assuming a normal distribution centered at 0 (Ducrocq, 2005). This transformation was performed because it is expected that culling for low production within herd is based on a ranking of the cows within herd rather than on their actual lactation production. In addition, an eleventh class was created to include short lactations (less than $60 \mathrm{~d})$ for which the extrapolation to a 305-d lactation is too inaccurate. Fat and PROT contents were classified in 5 classes, following the same procedure used for milk. As for production, an extra class (6) included fat and PROT from short lactations. Information on various families of traits that have an effect on culling decisions was also collected.

The investigated traits related to reproduction were the insemination status (INS) and the calving ease (CALV). The status of each AI was determined for each parity from the date of the subsequent calving and assuming a mean gestation length $(282 \mathrm{~d}$ for the French Holstein breed $\pm 15 \mathrm{~d}$ ). Once the successful insemination was found, all preceding inseminations were considered as failed, and all posterior inseminations during the same lactation were discarded. To properly mimic how the insemination status influences culling, it is necessary to make assumptions on what information is available to the farmer during the course of a cow's lactation. For example, the farmer does not immediately know the outcome of an AI for each cow. After a wait, the pregnant status can be determined using a pregnancy test or checking if the cow shows a new estrus or not. In French dairy farms, pregnancy exams were not routinely performed during all of the investigated period. In addition, results of pregnancy tests are not routinely recorded and the information is, at present, not available. In the case of a negative result from pregnancy test or if a new heat is detected, the farmer can choose between inseminating the cow again or not. Conversely, in presence of a positive pregnancy exam or if there is no new heat, the farmer can usually consider her as pregnant. We assumed a delay of 2 mo after the last AI performed to consider that the farmer knows the pregnant status of the cows. However, the definite success of AI is only known in the case of birth of the calf, given that an abortion can occur (information about miscarriages was not available in our data set). In this study, we tested 2 different classifications for INS, taking into account or not retrospective information about the pregnant status of the animals. The first classification (INS1) was aimed at modeling the actual level of knowledge of the farmer by including the following time-dependent classes: class 0 for complete absence of any information about any AI performed and their status during the ongoing lactation; class 1 to class 4 representing unknown outcome of the last AI, this last AI being respectively the first, second, third, or fourth one of the current lactation; class 5 to class 8 represent the cases where the farmer is considered to know the pregnancy status of the cow (because the farmer has the result of a pregnancy test or assumes that the cow is pregnant because no new heat is detected), starting 2 mo after the last AI and depending whether this AI is respectively the first, second, third, or fourth AI after calving. The second classification (INS2) included retrospective information about the real success of AI: from the complete data file, it is often known which cows were definitely pregnant because they had a next calving recorded. The categories for INS2 were as for INS1 with the addition of the following classes: class 9 to class 12 correspond to cows definitely pregnant 2 mo after respectively their first, second, third, or fourth AI. For INS1 and INS2, all posterior AI (fifth or more) were ignored.

For each new calving, calving ease was scored by the farmers themselves as 1 (no assistance), 2 (slight assistance), 3 (difficult assistance), or 4 (cesarean section or fetotomy).

Clinical mastitis (CM) events occurring during a given lactation were counted and classified in 5 classes reflecting successive occurrences (class 0: no CM, class 1: first CM event; class 2: second CM event, class 3: third CM event; class 4: fourth and subsequent CM events). When $2 \mathrm{CM}$ were recorded within $10 \mathrm{~d}$, they were considered as the same occurrence and only the first event was kept.

Similarly, the number of TD per lactation with a SCC higher than 300,000 cells $/ \mathrm{mL}$ was counted. This number was used to define 7 consecutive classes from 0 (no TD with $\mathrm{SCC}>300,000$ cells $/ \mathrm{mL}$ so far during the current lactation) to 6 (6 or more TD with SCC $>300,000$ cells $/ \mathrm{mL}$ ).

Each event of DA and MF was coded as 1 (presence). The absence of event during the current lactation was coded as 0 . In case of multiple events of DA and MF for one lactation, only the first one was considered. Moreover, only the events of MF recorded within $10 \mathrm{~d}$ before 
or after calving were included, and declared to occur at d 1 of the current lactation.

Animals showing events for these 2 diseases were classified into 2 classes: class 1 represents cows that developed the disease and were culled during the lactation when the disease event occurred, whereas class 2 includes animals that exhibited the disease but were culled in a subsequent lactation.

Among type traits, we selected 9 traits a priori believed to have a potential effect on risk of culling: BCS, stature (STAT), body depth (BDE), udder depth (UDE), udder balance (UDB), teat length (TLS), and feet and legs score (FLS), which were scored from 1 to 9 by a trained classifier. Temperament (TEMP) and milking speed (MSP) were scored from 1 to 5 by the farmer and collected at the same time. Morphology traits were recorded only once during first lactation, at any stage of lactation. It was expected that the link between those traits and the probability to be culled varies during the lactation. To correct for the moment of recording, an extra effect (REC_TYPE) with 4 classes was added to the model (class 1: 0 to 3 mo after the calving date; class 2: 3 to 6 mo; class 3: 6 to 9 mo; class 4: more than 9 mo after the calving date).

In addition, we computed the following explanatory variables to be used in the survival analysis model: herd-year (HY); age at first calving in months (Age), classified in 23 monthly classes from 20 to 42 mo; yearseason (YS), classified in 47 classes (12 yr from 2007 to $2018 \times 4$ seasons); and interaction between herd size and annual variation of herd size (HVAR). This effect, changing at the beginning of each trimester, was classified in 14 classes as follows: class 1 represents herds with less than 5 cows; classes 2 to 4 represent herds having from 5 to 19 cows with a decrease in herd size of more than $10 \%$, stable size, and an increase of more than $10 \%$, respectively; classes 5 to 9 represent herds having from 20 to 49 cows with a decrease in herd size of more than $15 \%$, decrease of 5 to $15 \%$, stable size, increase of 5 to $15 \%$, and increase of more than $15 \%$, respectively; classes 10 to 14 represent herds with 50 or more cows with a decrease in herd size of more than $15 \%$, decrease of 5 to $15 \%$, stable size, increase of 5 to $15 \%$, and increase of more than $15 \%$, respectively. To properly model the within-lactation increase of risk to be culled, these variables could change at each lactation stage (number of days since the most recent calving with changes at $0,270,380 \mathrm{~d}$, and when dry). These factors have an effect on the probability of a cow being culled during her productive life. The factors are routinely included in the French genetic evaluation of functional longevity (Ducrocq, 2005).

\section{Survival Analysis}

Survival Trait Definition. Length of productive life was used as a measure of longevity and it was calculated as the time between the date of first calving and date of culling. Cows leave the herd because of death or disposal, in which case their LPL was considered as uncensored. When culling had not occurred yet, the record was considered as censored. Censored records included LPL of animals still alive at an overall limit date (August 31, 2018) or at the date of end of the CDR period for their herd, if it occurred earlier. In addition, cows that moved to another herd were considered as censored at the date of the first change of herd. Their productive life in the second herd was not included in the analysis. Cows with more than 5 lactations were censored at the date of the end of their fifth lactation. Finally, animals with lactation length longer than $800 \mathrm{~d}$ were censored at that day to avoid unrealistically long lactations, probably due to missing information. Cows with a date of first calving after the limit date (August 31, 2018) were ignored.

Weibull Proportional Hazard Models. The influence of the factors related to fertility, morphology, and health status on TL and FL were evaluated using a proportional hazard model assuming a piecewise Weibull distribution of the baseline hazard function. It has been shown that such a model provides a good approximation of a semi-parametric (Cox) model, while being much less computationally demanding (Ducrocq, 2005).

All the effects tested in the present studies are listed in Table 1. Two different base models were used to study TL and FL, respectively. The statistical base model used to evaluate TL was as follows:

$$
\begin{aligned}
\lambda_{i j k l}(t)=\lambda_{0 n p}\left(t^{\prime}\right) \exp [ & Y S_{i}(t)+A g e_{j}+H V A R_{k}(t) \\
+ & \left.H Y_{l}(t)\right]
\end{aligned}
$$

where $\lambda_{i j k l}(t)$ is the hazard function of the cow at time $t ; \lambda_{0}\left(t^{\prime}\right)$ is a piecewise Weibull baseline hazard function for the $n$th lactation stage ( 1 to 4 , with changes at $d$ 270,365 , and when the cow was dried, class 4 being the dry period) of the $p$ th parity ( 1 to 5 ) with specific scale parameter $\lambda$ and shape parameter $\rho$ for each lactation $\times$ stage combination and with $t^{\prime}$ being the number of days since the beginning of the current lactation (as in Ducrocq, 2005). This resulted in 19 baseline hazard functions (4 for each lactation, except for the fifth one for which the dry period is ignored). All effects in the exponential part of [1] are time-dependent effects, except the age at first calving effect. 
Table 1. Description of the factors investigated in the present study

\begin{tabular}{|c|c|c|c|c|}
\hline Effect & Description & Definition & Type & $\begin{array}{l}\text { Time } \\
\text { dependent }\end{array}$ \\
\hline $\mathrm{Age}_{j}$ & Age at first calving & Monthly classes from 20 to $42 \mathrm{mo}$ & Fixed & No \\
\hline$H V A R_{k}$ & $\begin{array}{l}\text { Interaction between herd size } \times \text { annual } \\
\text { variation of herd size }\end{array}$ & 14 classes & Fixed & Yes \\
\hline$Y S_{i}$ & Calving year $\times$ season interaction & 12 years from 2007 to $2018 \times 4$ seasons & Fixed & Yes \\
\hline Milk $_{m}$ & Within-herd milk yield & 11 classes & Fixed & Yes \\
\hline $\mathrm{Fat}_{n}$ & Within-herd fat content & 6 classes & Fixed & Yes \\
\hline$C A L V \times P_{p}$ & Calving ease $\times$ parity interaction & $\begin{array}{l}5 \text { calving ease classes } \times 2 \text { parity (first } \\
\text { and later) }\end{array}$ & Fixed & Yes \\
\hline$C M_{p}$ & Clinical mastitis & 6 classes & Fixed & Yes \\
\hline$S C C_{p}$ & Somatic cell count & 7 classes & Fixed & Yes \\
\hline$B C S_{p}$ & Body condition score & 10 classes & Fixed & Yes \\
\hline$S T A T_{p}$ & Stature score & 10 classes & Fixed & Yes \\
\hline$B D E_{p}$ & Body depth score & 10 classes & Fixed & Yes \\
\hline$M S P_{p}$ & Milking speed score & 6 classes & Fixed & Yes \\
\hline$D A_{p}{ }^{p}$ & Displaced abomasum & 5 classes & Fixed & Yes \\
\hline$M F_{p}$ & Milk fever & 5 classes & Fixed & Yes \\
\hline$R E C_{-} T Y P E_{q}$ & Moment of recording for type traits & 4 classes & Fixed & No \\
\hline$H Y_{l}$ & Herd $\times$ year effect & With log-gamma distribution & Random & Yes \\
\hline
\end{tabular}

The statistical base model used to evaluate FL was as model [1] but included the extra effect of milk production traits:

$$
\begin{aligned}
& \lambda_{i j k l m n o}(t)=\lambda_{0 n p}\left(t^{\prime}\right) \exp \left[Y S_{i}(t)+A g e_{j}+H V A R_{k}(t)\right. \\
& \left.\quad+H Y_{l}(t)+\operatorname{Milk}_{m}(t)+\text { Fat }_{n}(t)+\operatorname{PROT}_{o}(t)\right],
\end{aligned}
$$

where $\operatorname{Milk}_{m}(t)$ is the $m$ th within-herd milk yield class, $F_{a t}(t)$ is the $n$th within-herd fat content class, and $\operatorname{PROT}_{o}(t)$ is the oth within-herd protein content class. For type traits, as indicated above, the fixed time-independent effect of REC_TYPE was also added to the 2 base models to take into account the period of recording. Each effect related to reproduction, morphology, and health status was individually added to the 2 base models and tested one at a time.

To evaluate whether the addition of a new factor to a base model significantly improves the goodness of fit, log-likelihood ratio tests (LRT) statistics were used for model comparison. The LRT test statistics were calculated as

$$
\begin{aligned}
\mathrm{LRT} & =-2[\log \mathrm{L}(\text { reduced model }) \\
& -\log \mathrm{L}(\text { full model })]
\end{aligned}
$$

where $\log \mathrm{L}$ is the $\log$-likelihood of a model. These statistics follow a chi-squared distribution with as many degrees of freedom as the number of estimable parameters added to the base models (either TL or FL).

Survival analysis was performed using the Survival Kit software (v6.12, Mészáros et al., 2013).

\section{RESULTS AND DISCUSSION}

\section{Survival Analysis}

The average within lactation failure time was 301, indicating that culling occurs in general toward the end of the lactation. The percentage of right-censored records was $47.7 \%$. The minimum and maximum censoring times within lactation were 1 and $800 \mathrm{~d}$, respectively $($ mean $=250 \mathrm{~d})$.

\section{Likelihood Ratio Tests}

Likelihood ratio tests were used to compare the ability of the investigated models to fit the data. The 2 base models for TL and FL were the reduced models. Results are reported in Table 2.

All the investigated factors, except MF, improved the goodness of fit of the base models, showing a highly significant $(P<0.01)$ relationship with TL and FL. Insemination status was the trait with the strongest relationship with longevity, confirming the central importance of fertility in culling decisions (Olechnowicz 
et al., 2016). Among type traits, UDE was the trait showing the largest influence on TL and FL. This is in agreement with previous studies investigating the influence of conformation traits on LPL (e.g., Larroque and Ducrocq, 2001; Zavadilová et al., 2011).

\section{Survival Analysis}

Milk Production Traits. Survival analysis models to evaluate FL included time-dependent fixed effects related to milk production traits. Table 3 reports relative risks ( $\mathbf{R R}$ ) of being culled for milk, fat, and PROT. The RR for milk decreased continuously from class 1 (worst within herd-year milk class) to class 10 (best within herd-year milk class). Cows with a decrease in within herd-year milk (classes 1 to 4 ) showed significantly higher $\mathrm{RR}$ with respect to the reference class $($ milk $=5)$. Conversely, cows with an increase of within herd-year milk (classes 6 to 10) had lower RR than the reference class. Relative risk for cows in class 1 is much higher than for animals in the other milk classes, suggesting that large negative, within herd-year deviations of milk yield had a strong effect on culling. Cows with a lactation length $<60 \mathrm{~d}($ milk $=11)$ showed a higher risk of being culled with respect to other milk classes, which simply reflects that lactations shorter than $60 \mathrm{~d}$ are rare in the absence of early culling.

Risk ratios for fat and PROT decreased from class 1 (worst within herd-year fat or PROT class) to class 5 (best within herd-year fat or PROT class). These results are consistent with previous studies (Samoré et al., 2003; Ducrocq, 2005).

Traits Related to Reproduction. The 2 traits associated with reproduction are INS and CALV. Table 4 reports the relative risk of being culled for INS for the 2 classifications proposed. The first one (INS1) makes use of the recorded information available when a farmer takes the decision to cull an animal or not; the second one (INS2) takes into account retrospective information about the pregnancy status of the animals. The true situation is probably intermediate: after several unsuccessful inseminations, a farmer may decide to stop inseminating her and to cull the cow at the end of her lactation (or before). However, the exact moment when this decision is taken is not available in any database. As a proxy, our modeling assumes that the farmer does not know whether an insemination is successful during the first 2 mo after insemination. After these $2 \mathrm{mo}$, it is supposed that either the farmer knows that the cow is pregnant or the farmer knows that the cow is not pregnant and then decides to cull her when she becomes less productive. The class representing cows with a (yet) unknown outcome after the first AI (class 1) was chosen as the reference class. As it could be expected, cows that were not inseminated had a much higher risk of being culled than inseminated, supposed pregnant, or pregnant animals. The cows not inseminated were probably considered not suitable for another lactation by the farmer due to low milk production, reproductive problems in previous lactations,

Table 2. Likelihood ratio test for the investigated models ${ }^{1}$

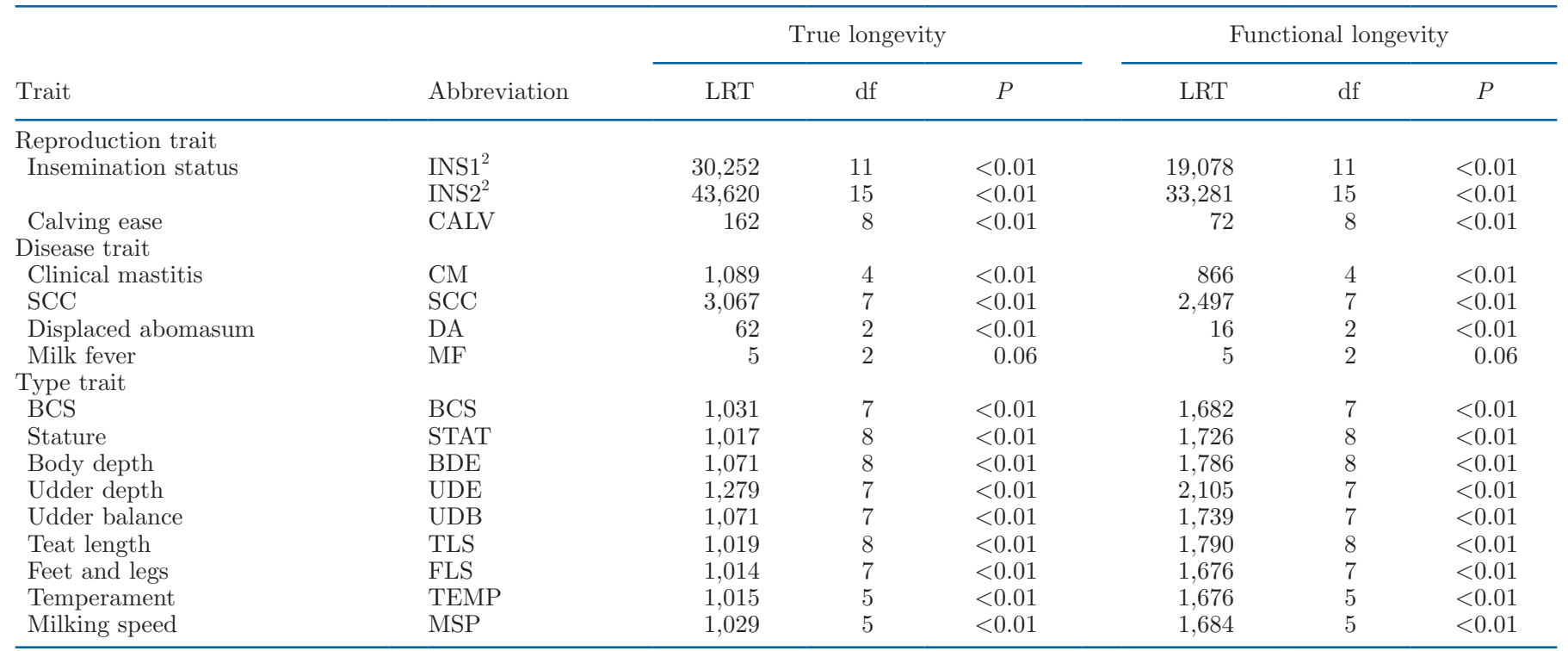

${ }^{1} \mathrm{LRT}=\chi^{2}$ test statistic for the likelihood ratio test $=-2$ (LogLreduced model - LogLfull model), in which LogL is the log-likelihood and df is the degrees of freedom for the $\chi^{2}$ test statistic.

${ }^{2} \mathrm{INS} 1$ = insemination status based on AI information only; INS2 = insemination status including retrospective information about the pregnant status of the cows. 
or other health troubles. The fact that some of them survive is certainly due to incomplete information (e.g., the cow got pregnant through a natural service) or cows calving just before the end of the study. The risks of being culled for cows inseminated but with an as yet unknown outcome were lower compared with animals for which the farmer knew their pregnant status (classes 1 to 4 vs. 5 to 8). This indicates that farmers tend to wait until they know the success or failure of the insemination before deciding to cull their cows. The RR for cows with known outcome (classes 5 to 8) were lower with INS1 compared with with INS2. In addition, the risks to be culled for definitely pregnant cows (classes 9 to 12) were very low compared with those in classes 5 to 8 . This suggests that in the classes including cows with known pregnant status after 2 mo

Table 3. Relative risk of culling for within herd-year deviations for milk yield (milk), fat, and protein (PROT) contents $^{1}$

\begin{tabular}{lcr}
\hline $\begin{array}{l}\text { Milk production } \\
\text { trait class }\end{array}$ & $\begin{array}{c}\text { Relative risk } \\
\text { of culling }\end{array}$ & $\begin{array}{c}\text { Uncensored } \\
\text { failures }\end{array}$ \\
\hline Milk & $29.52^{* *}$ & 12,329 \\
1 & $4.36^{* *}$ & 4,115 \\
2 & $2.20^{* *}$ & 4,225 \\
3 & $1.38^{* *}$ & 4,596 \\
4 & 1.00 & 5,289 \\
$5^{3}$ & $0.75^{* *}$ & 5,426 \\
6 & $0.60^{* *}$ & 5,458 \\
7 & $0.49^{* *}$ & 4,836 \\
8 & $0.42^{* *}$ & 3,704 \\
9 & $0.32^{* *}$ & 1,670 \\
10 & $392.76^{* *}$ & 6,201 \\
11 & & \\
Fat & $1.13^{* *}$ & 8,745 \\
1 & 1.03 & 11,790 \\
2 & $1.00^{*}$ & 11,702 \\
$3^{3}$ & $0.97^{*}$ & 10,488 \\
4 & $0.82^{* *}$ & 8,923 \\
5 & 1.00 & 6,201 \\
$6^{4}$ & & \\
PROT & $1.56^{* *}$ & 9,791 \\
1 & $1.13^{* *}$ & 12,884 \\
2 & 1.00 & 12,500 \\
$3^{3}$ & $0.86^{* *}$ & 9,813 \\
4 & $0.64^{* *}$ & 6,660 \\
5 & 1.00 & 6,201 \\
$6^{4}$ & & \\
\hline
\end{tabular}

${ }^{1}$ Significance of the $x^{2}$ statistic, testing the difference between risk ratios associated with each level and that of the reference class (class 5 for milk; class 3 for fat and PROT).

${ }^{2}$ Milk was classified in 10 classes using within herd-year deviations of 305-d milk yield from bottom $10 \%$ (class 1) to top $10 \%$ (class 10 ). The eleventh class included cows with lactation length $<60 \mathrm{~d}$. Fat and PROT were classified in 5 classes using within herd-year deviations of 305-d fat or PROT contents from bottom 20\% (class 1) to top 20\% (class 5). The sixth class included cows with lactation length $<60 \mathrm{~d}$.

${ }^{3}$ Reference class.

${ }^{4}$ Relative risk for class 6 for fat and PROT were fixed to 1 . In fact, they are not estimable at the same time with class 11 for milk because these classes strictly include the same animals.

${ }^{*} P<0.05 ;{ }^{*} P<0.01$. (under INS1), there are 2 groups of animals: the cows certainly pregnant that gave birth to a calf, and the animals for which farmers decided to stop insemination. For both groups of animals inseminated, with or without a known outcome, RR were higher after the first and fourth AI than after the second and third AI. Given that different AI occurred in different lactation stages, estimates of RR can be affected by the time when cows were inseminated. Further investigation of the interaction between lactation stage and pregnancy status may help to better understand the influence of INS on longevity (e.g., as in Gröhn et al., 1997).

Calving difficulty is a direct risk factor for culling (Beaudeau et al., 2000). The RR of culling for CALV in primiparous and multiparous cows are presented in Figure 1. The effect of the interaction between parity (primiparous vs. multiparous cows) and CALV was investigated. The class representing unassisted calvings $(\mathrm{CALV}=1)$ was chosen as the reference class for both primiparous and multiparous cows. When LPL was not adjusted for milk production (TL), both primiparous and multiparous cows showed a higher risk of being culled after a calving needing assistance with respect to the reference class $(\mathrm{CALV}=1)$, and the risk ratios were larger when calving difficulties increased. Similarly, primiparous cows whose calving needed assistance (CALV $=2$ and $\mathrm{CALV}=3$ ) and multiparous cows whose calving needed slight assistance $(\mathrm{CALV}=2)$ showed greater RR with respect to the reference class. In addition, when FL was analyzed, the risk of being culled for cows having very difficult calvings (with cesarean section or fetotomy; CALV = 4) was not significantly different with respect to the $\mathrm{RR}$ for the animals with unassisted calvings $(\mathrm{CALV}=1)$. This surprising result may be due to a low number (230) of such observations or proper assistance by a veterinarian, whose cost is an incentive to keep the cow for an additional lactation to recover the expense. These results are consistent with previous studies (López de Maturana et al., 2007; Sewalem et al., 2008). In addition, RR for FL were lower than for TL. As reported by Dematawena and Berger (1997), difficult calvings are associated with a decrease in 305-d adjusted milk, fat, and protein yield. Consequently, farmers are more prone to cull cows experiencing assisted calvings and not able to maintain a high milk production.

Clinical Mastitis and Somatic Cell Count. The $\mathrm{RR}$ of culling for the different CM classes are presented in Table 5. The class representing the complete absence of CM during a given lactation was chosen as the reference class. Cows that experienced at least one CM had a significantly higher risk of being culled than the animals in the reference class $(\mathrm{CM}=0)$. Animals with 4 or more events of $\mathrm{CM}$ had more than twice a risk 
of being culled than cows that did not experience the disease. Moreover, the RR continuously increased from class 1 (one $\mathrm{CM}$ during the lactation) to class 4 (4 CM or more). Gröhn et al. $(1997,1998)$ and Neerhof et al. (2000) reported similar trends. The increase in risk of culling across CM classes was quite similar for TL and FL, with a slightly higher level for TL than for FL for animals having 2 or 3 events of CM. A closer look at the proportion of $\mathrm{CM}$ events showed a quite similar incidence of $\mathrm{CM}$ across milk production classes with just a modest increase in class milk $=1$, which may be explained by the negative effect of mastitis on production. In fact, several studies (e.g., Wilson et al., 2004; Bar et al., 2007) showed a detrimental effect of CM on milk yield.

Table 6 summarizes RR for SCC classes. The class representing the absence of any high $\mathrm{SCC}(\mathrm{SCC}=0)$ was chosen as the reference class. Results for SCC were similar to (and consistent with) CM results. Cows with at least 2 TD with SCC higher than 300,000 cell $/ \mathrm{mL}$ (i.e., the level beyond which subclinical mastitis can be considered) had a significantly higher risk of being culled than animals in the reference class. From class 1 (one TD having SCC $>300,000$ cell $/ \mathrm{mL}$ ) to class 6 (more than 6 TD where $\mathrm{SCC}>300,000 \mathrm{cell} / \mathrm{mL}$ ), the RR increased continuously. As an example, the RR for cows in the class 6 was twice the RR of animals in the reference class. A negative effect of high concentrations of somatic cells on functional longevity was also found in previous studies of Samoré et al. (2003) and Sewalem et al. (2006). Comparison of estimations for TL and FL revealed that the risk of being culled due to high SCC was greater when longevity was not adjusted for milk production. As for CM, this suggests that farmers are not prone to keep in the herd cows with several TD having SCC >300,000 cell $/ \mathrm{mL}$. This may be explained by the reduced milk yield caused by subclinical mastitis and penalties in the milk payment system for milk of poor quality.

Other Diseases. Table 7 reports the RR for DA. The class representing the absence of DA $(\mathrm{DA}=0)$ was chosen as the reference class. When TL is considered, cows with the disease $(\mathrm{DA}=1)$ had a significantly higher risk of being culled than animals that did not exhibit DA. However, this risk is lower for FL (i.e., after correction for milk production traits). In contrast, both TL and FL are affected by DA during the subsequent lactations $(\mathrm{DA}=2)$ : in other words, the best cows among those with DA are more likely to be kept for an extra lactation to take advantage of their productivity during the current lactation and because the surgical intervention for a DA represents a cost that the farmer needs to recover. However, all cows experiencing DA surgery appear to be at a higher risk of being culled in

Table 4. Relative risk of culling associated with true (TL) or functional (FL) longevity as a function of the AI status of the cow ${ }^{1}$

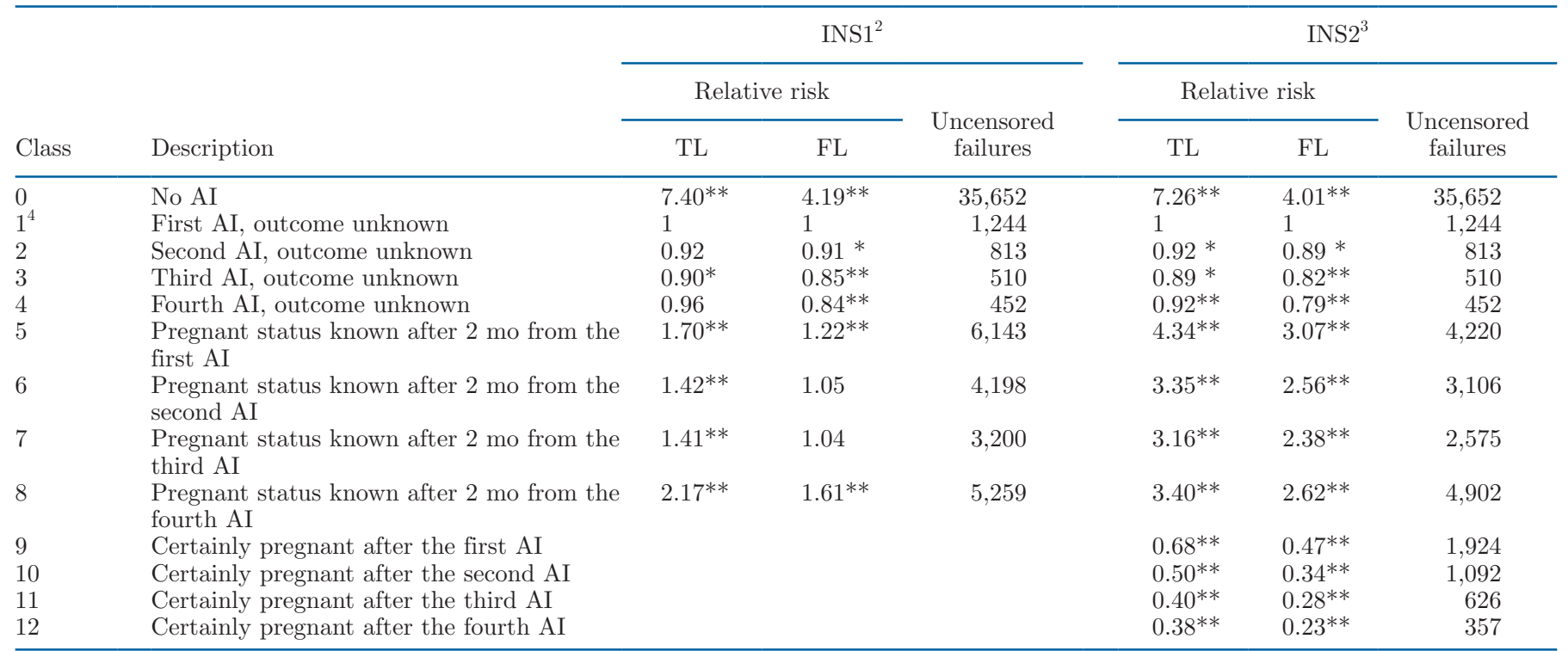

${ }^{1}$ Significance of the $\chi^{2}$ statistic, testing the difference between risk ratios associated with each insemination status level and that of the reference class.

${ }^{2}$ INS1 = classification of the trait that does not take into account retrospective information about the real success or failure of AI.

${ }^{3}$ INS2 = classification of the trait that considers retrospective information about the real success or failure of AI.

${ }^{4}$ Reference class.

${ }^{*} P<0.05 ;{ }^{* *} P<0.01$. 
Table 5. Relative risk of culling for clinical mastitis (CM) associated with true (TL) and functional (FL) longevity ${ }^{1}$

\begin{tabular}{lllll}
\hline & & \multicolumn{2}{c}{ Relative risk } & \\
\cline { 3 - 4 } $\mathrm{CM}$ & $\begin{array}{l}\text { Number of } \\
\text { CM events }\end{array}$ & $\mathrm{TL}$ & $\mathrm{FL}$ & \multirow{2}{*}{$\begin{array}{c}\text { Uncensored } \\
\text { failures }\end{array}$} \\
\hline $0^{2}$ & 0 & 1.00 & 1.00 & 43,874 \\
1 & 1 & $1.09^{* *}$ & $1.04^{* *}$ & 8,085 \\
2 & 2 & $1.48^{* *}$ & $1.39^{* *}$ & 3,410 \\
3 & 3 & $1.91^{* *}$ & $1.70^{* *}$ & 1,475 \\
4 & 4 or more & $2.10^{* *}$ & $2.18^{* *}$ & 1,005 \\
\hline
\end{tabular}

${ }^{1}$ Significance of the $\chi^{2}$ statistic, testing the difference between risk ratios associated with each $\mathrm{CM}$ level and that of the reference class $(\mathrm{CM}=0)$.

${ }^{2}$ Reference class.

** $P<0.01$.

later lactations. As reported in Detilleux et al. (1997), DA is associated with a decrease in milk yield, which can favor the culling of the animals because they are less productive.

The RR of culling after a MF are presented in Table 8. As found in the LRT analysis, this trait did not show a significant relationship with TL and FL. The review of Beaudeau et al. (2000) reported that the previous studies investigating the effect of MF on longevity found opposing results. With regard to our study, it is important to consider that information for MF was collected from diaries filled out by the farmers. Given that the recordings were not performed by a veterinarian, preventive treatments may have been recorded erroneously as MF events for some cows, which may explain the absence of increased relative risk of culling for MF.
Table 6. Relative risk of culling for SCC associated with true (TL) and functional (FL) longevity ${ }^{1}$

\begin{tabular}{|c|c|c|c|c|}
\hline \multirow[b]{2}{*}{$\mathrm{SCC}$} & \multirow{2}{*}{$\begin{array}{c}\text { Number of } \\
\text { test-days with SCC } \\
>300,000 \text { cells } / \mathrm{mL}\end{array}$} & \multicolumn{2}{|c|}{ Relative risk } & \multirow{2}{*}{$\begin{array}{l}\text { Uncensored } \\
\text { failures }\end{array}$} \\
\hline & & TL & FL & \\
\hline$\overline{0^{2}}$ & 0 & 1.00 & 1.00 & 35,401 \\
\hline 1 & 1 & 1.00 & $0.94^{* *}$ & 6,754 \\
\hline 2 & 2 & $1.46^{* *}$ & $1.25^{* *}$ & 4,256 \\
\hline 3 & 3 & $1.69^{* *}$ & $1.45^{* *}$ & 2,901 \\
\hline 4 & 4 & $1.93^{* *}$ & $1.67^{* *}$ & 2,305 \\
\hline 5 & 5 & $2.05^{* *}$ & $1.89^{* *}$ & 1,719 \\
\hline 6 & 6 or more & $2.20^{* *}$ & $2.11^{* *}$ & 4,217 \\
\hline
\end{tabular}

${ }^{1}$ Significance of the $\chi^{2}$ statistic, testing the difference between risk ratios associated with each SCC level and that of the reference class $(\mathrm{SCC}=0)$.

${ }^{2}$ Reference class.

$* * P<0.01$.

Type Traits. Risk ratios for BCS, STAT, and BDE are presented in Figures 2A, B, C. When LPL was not adjusted for milk production (TL), cows having high scores for BCS (Figure 2A) showed a greater risk of being culled than animals in the reference class $(\mathrm{BCS}=$ $5)$. In addition, for fat cows $(\mathrm{BCS}=7$ and $\mathrm{BCS}=8)$, the risk of being culled for TL was greater than for FL. This finding is consistent with the reported negative relationship between BCS and milk yield (Berry et al., 2003).

Stature did not have a strong influence on TL. As shown in Figure 2B, only very tall cows $(\mathrm{STAT}=9)$ had a RR of being culled that was significantly different from the animals in the reference class $(\mathrm{STAT}=5)$. The risk of being culled for tall cows was 1.2 and 1.1

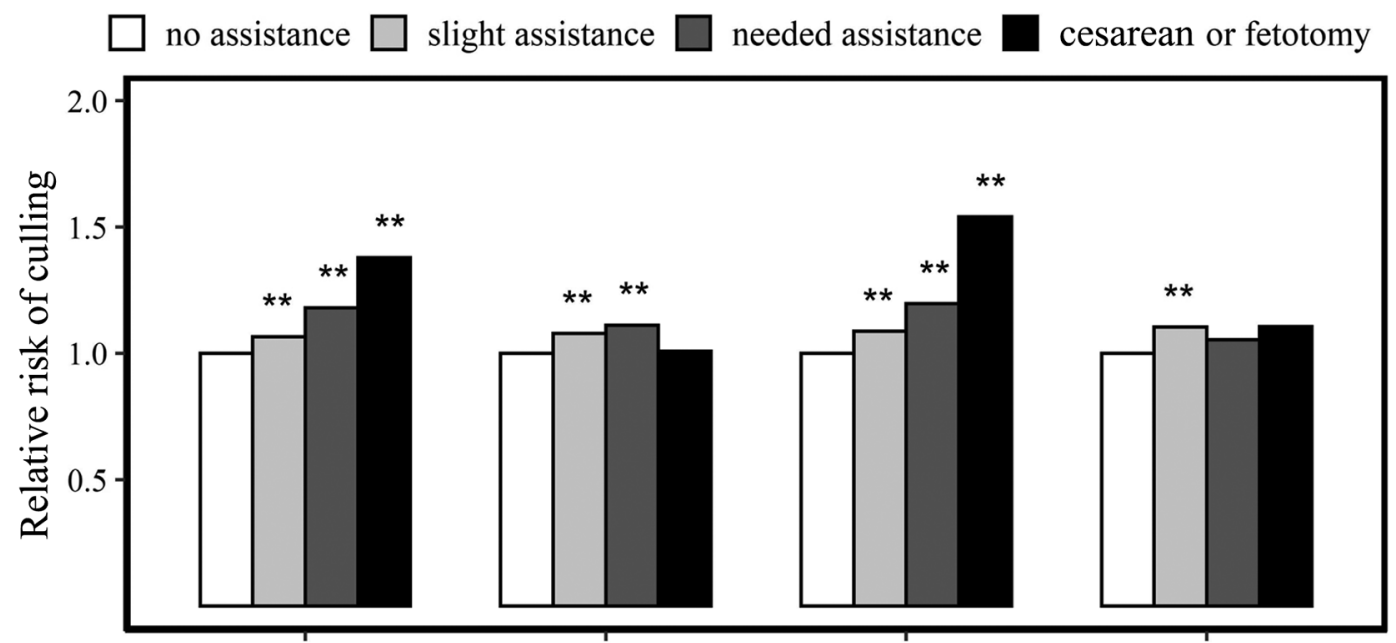

Primiparous cows TL Primiparous cows FL Multiparous cows TL Multiparous cows FL Calving ease (score)

Figure 1. Relative risk of culling for calving ease in primiparous and multiparous cows associated with true (TL) and functional (FL) longevity. Significance of the $\chi^{2}$ statistic, testing the difference between risk ratios associated with each calving ease score level and class 1 (no assistance) chosen as the reference class for both primiparous and multiparous cows. ${ }^{* *} P<0.01$. 
Table 7. Relative risk of culling for displaced abomasum (DA) associated with true (TL) and functional (FL) longevity ${ }^{1}$

\begin{tabular}{|c|c|c|c|c|}
\hline DA & Description & \multicolumn{2}{|c|}{ Relative risk } & $\begin{array}{l}\text { Uncensored } \\
\text { failures }\end{array}$ \\
\hline $0^{2}$ & Absence of DA & 1.00 & 1.00 & 46,555 \\
\hline 2 & Presence of DA and culling in a subsequent lactation & $1.39^{* *}$ & $1.21^{* *}$ & 330 \\
\hline
\end{tabular}

times higher than for animals in the reference class. Reduced longevity for tall cows was also found in previous studies (e.g., Zavadilová et al., 2011).

Relative risks associated with BDE are shown in Figure 2C. Animals with large BDE (BDE $\geq 7$ ) showed a risk of being culled that was significantly higher than cows belonging to the reference class $(\mathrm{BDE}=5)$ for both TL and FL. As an example, the risk of being culled for cows belonging to class 9 was 1.3 times higher than that of animals in the reference class. This is consistent with the results of Larroque and Ducrocq (2001). Moreover, for those cows, RR associated with TL were lower with respect to the risk of being culled for FL. This suggests that within these classes, the most productive animals are somewhat protected from culling.

Estimated risk ratios for udder traits are shown in Figures 3A, B, and C. Based on LRT analysis, UDE is the type trait with the strongest influence on TL and FL. Relative risks for UDE (Figure 3A) were much higher and significantly different from those for the reference class (UDE $=5$ ) for cows with the udder floor below hock level (UDE $\leq 4)$. In contrast, cows having udder floor above hock level (UDE $\geq 6$ ) had a lower risk of being culled with respect to the reference class. Cows with low scores for the trait showed smaller RR for TL than for FL. Conversely, the risk of being culled associated with TL was higher than FL for animals with UDE $>6$. This suggests that udder depth score is somewhat corrected for production by the farmer when taking a culling decision: a very deep udder is more unacceptable if the cow is not a good producer and a shallow udder is even more favored for high-producing cows. Norman et al. (1988) and Larroque and Ducrocq (2001) found similar results.

Relative risks for UDB are depicted in Figure 3B. Cows having the rear quarters deeper than the front quarters $(\mathrm{UDB}=2$ and $\mathrm{UDB}=3$ ) showed higher risk of being culled than animals in the reference class (UDB $=5)$, whereas slightly higher front quarters significantly reduce culling risk (this was not found for UDB scores $\geq 7$ but they are relatively rare).

Teat length (Figure $3 \mathrm{C}$ ) did not show a strong influence on longevity. In fact, there were no significant differences between RR estimated for animals with extreme scores for TLS and cows in the reference classes for the trait. The absence of effect of teat traits on FL in French Holstein cows was also found in Larroque and Ducrocq (2001).

Relative risks for FLS are presented in Figure 4A. Cows with poor FLS had a higher risk of being culled than animals in the reference class $(\mathrm{FLS}=5)$ for both TL and FL. The welfare impact for the cows and the economic impact of lameness on the herd (Onyiro et al., 2008) can favor the culling of cows with impaired locomotion from the herd. No significant differences between risks to be culled for animals with very good feet and legs and those in the reference class were found.

As shown in Figure 4B, TEMP did not show strong effects on longevity, although slightly nervous cows had a significantly lower culling risk for FL with respect

Table 8. Relative risk of culling for milk fever (MF) associated with true (TL) and functional (FL) longevity ${ }^{1}$

\begin{tabular}{|c|c|c|c|c|}
\hline \multirow[b]{2}{*}{$\mathrm{MF}$} & \multirow[b]{2}{*}{ Description } & \multicolumn{2}{|c|}{ Relative risk } & \multirow{2}{*}{$\begin{array}{c}\text { Uncensored } \\
\text { failures }\end{array}$} \\
\hline & & $\mathrm{TL}$ & $\mathrm{FL}$ & \\
\hline$\overline{0^{2}}$ & Absence of MF & 1 & 1 & 52,038 \\
\hline 1 & Presence of MF and culling in the same lactation of the disease & $0.92^{*}$ & 0.93 & 685 \\
\hline 2 & Presence of MF and culling in a subsequent lactation & 1.03 & 1.08 & 363 \\
\hline
\end{tabular}




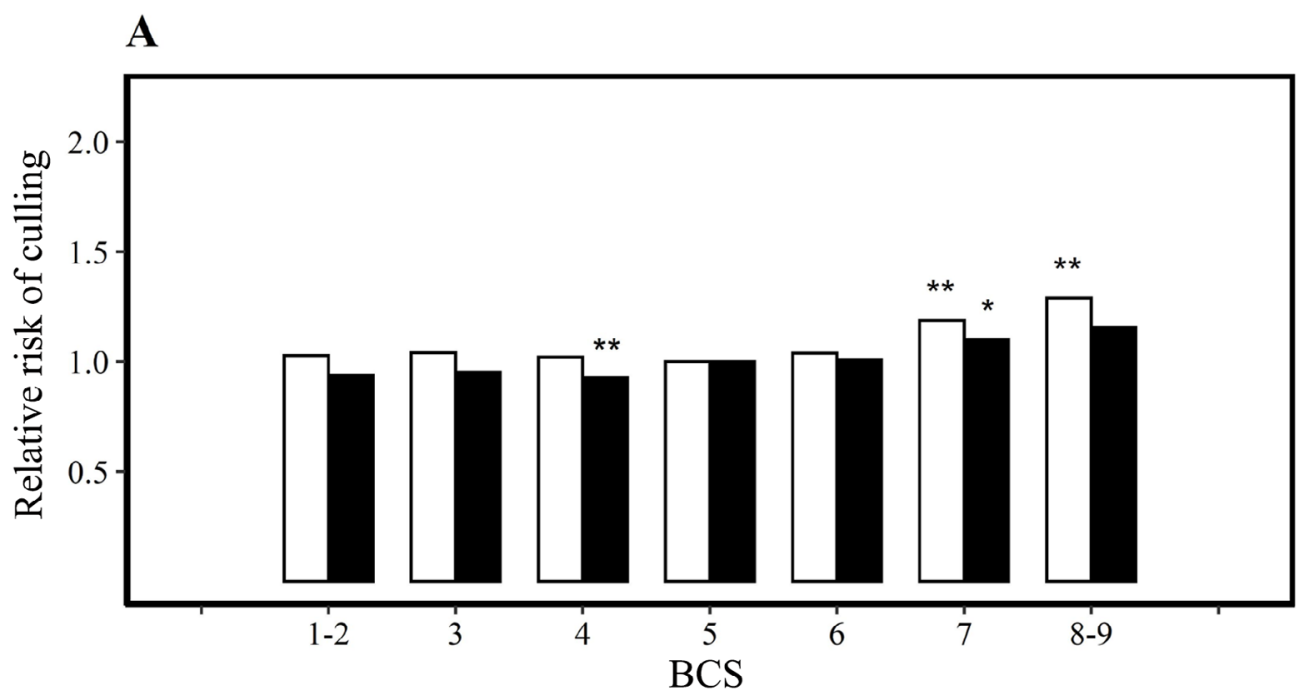

B

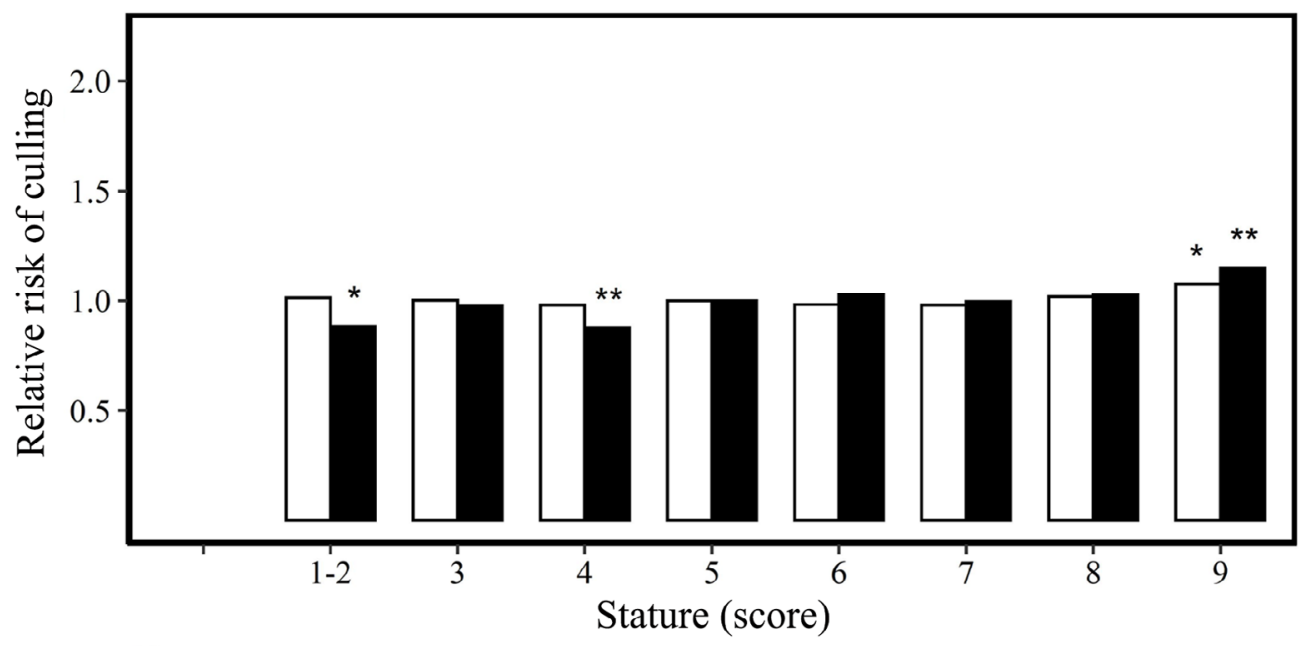

C

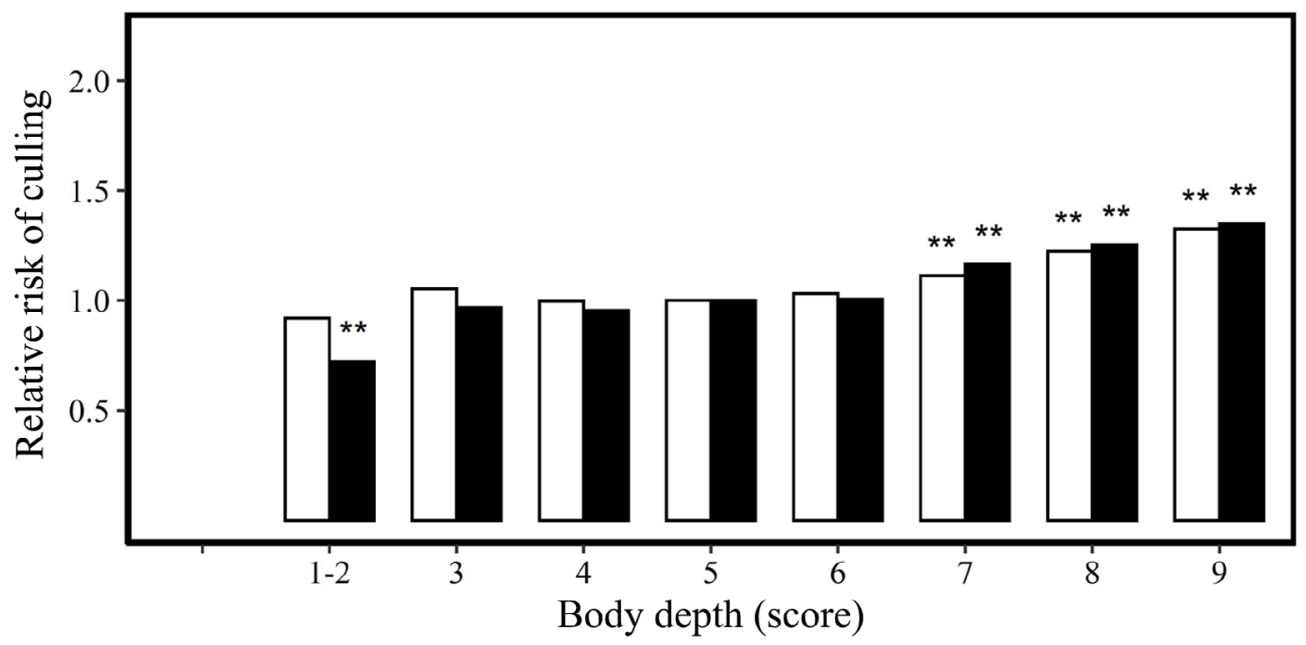

Figure 2. Relative risk of culling for BCS, stature, and body depth associated with true (white bars) and functional (black bars) longevity. Body condition was scored from 1 (thin) to 9 (fat); stature was scored from 1 (small) to 9 (tall); body depth was scored from 1 (shallow) to 9 (deep). The reference class for BCS, stature, and body depth is score 5. Significance of the $\chi^{2}$ statistic, testing the difference between risk ratios associated with each trait level and that of the reference class; ${ }^{*} P<0.05 ;{ }^{*} P<0.01$. 
A

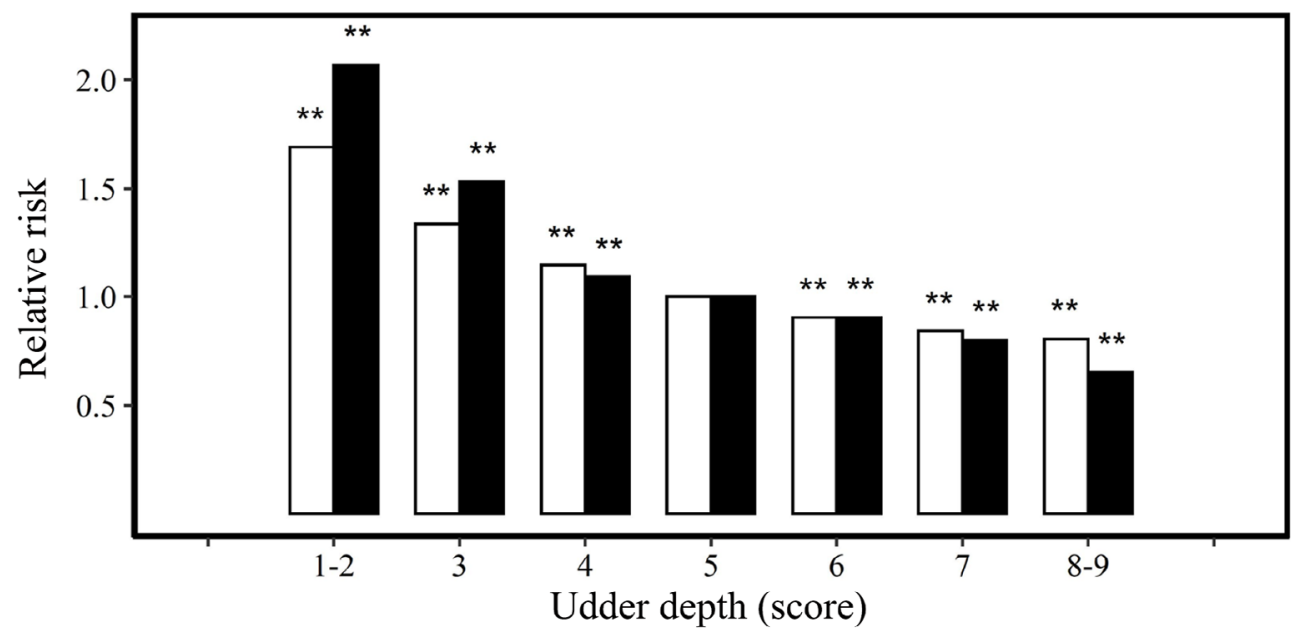

B

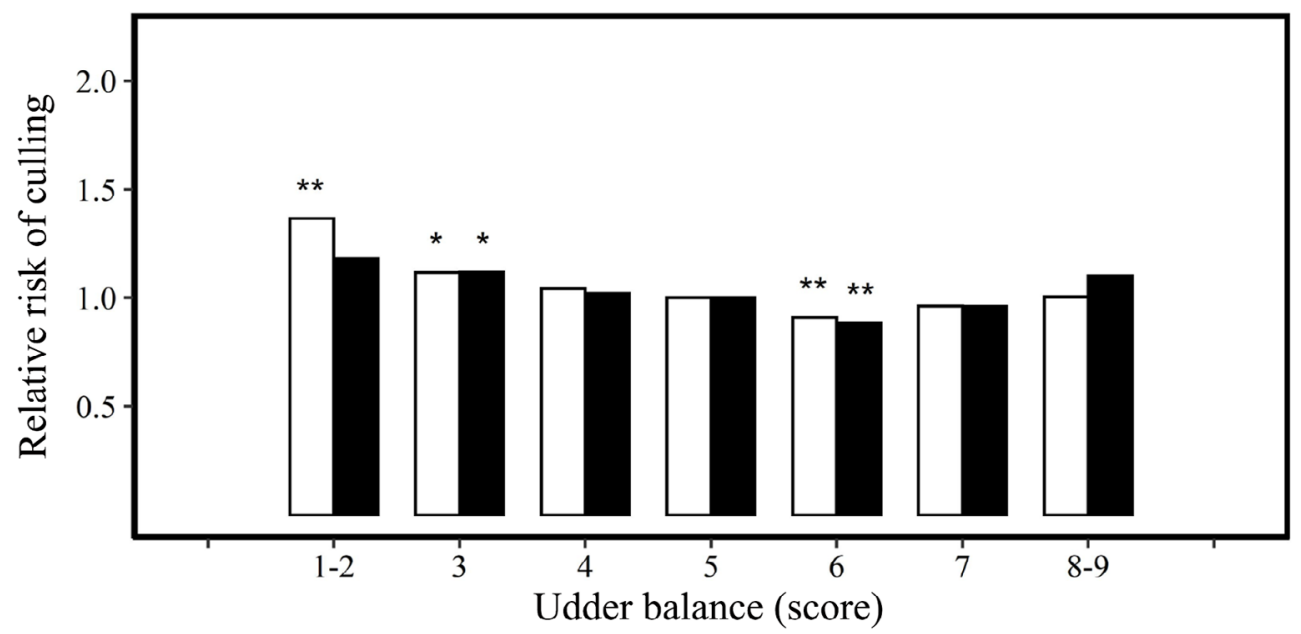

C

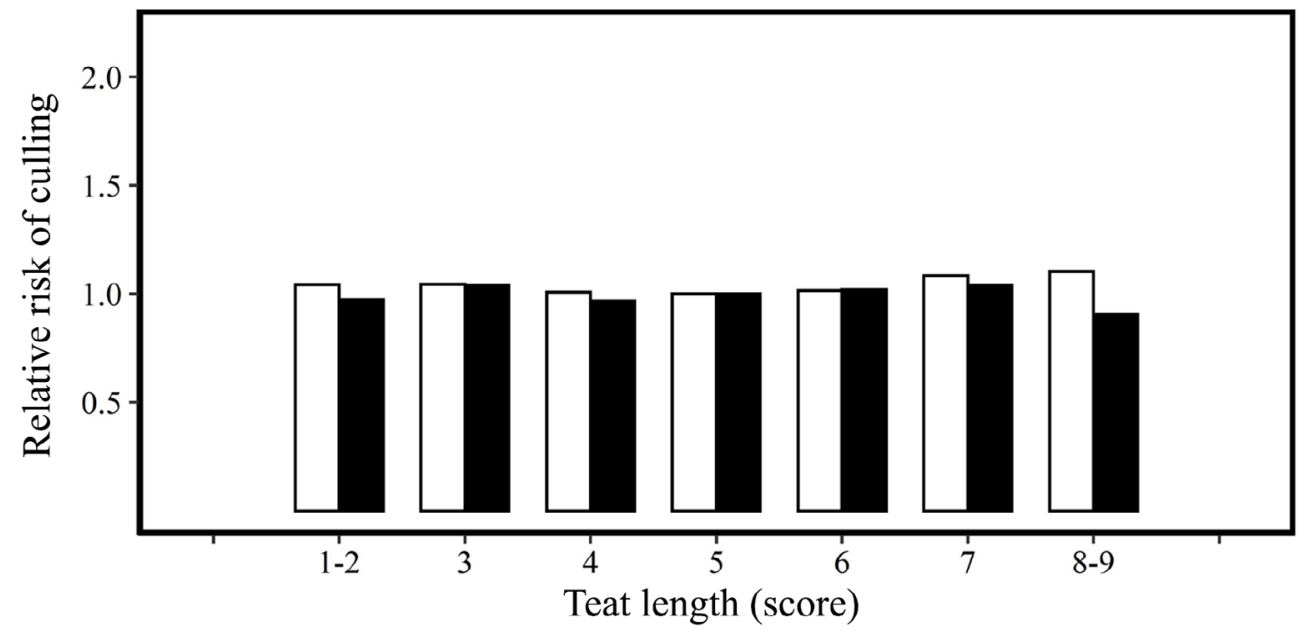

Figure 3. Relative risk of culling for udder depth, udder balance, and teat length associated with true (white bars) and functional (black bars) longevity. Udder depth was scored from 1 (udder floor below hock level) to 9 (udder floor above hock level); udder balance was scored

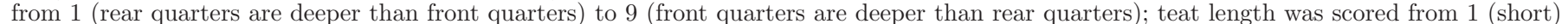

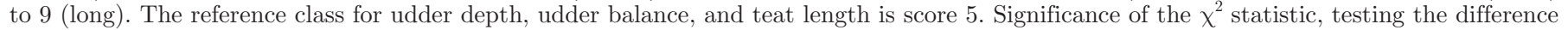
between risk ratios associated with each trait level and that of the reference class; ${ }^{*} P<0.05 ; * * P<0.01$. 
A

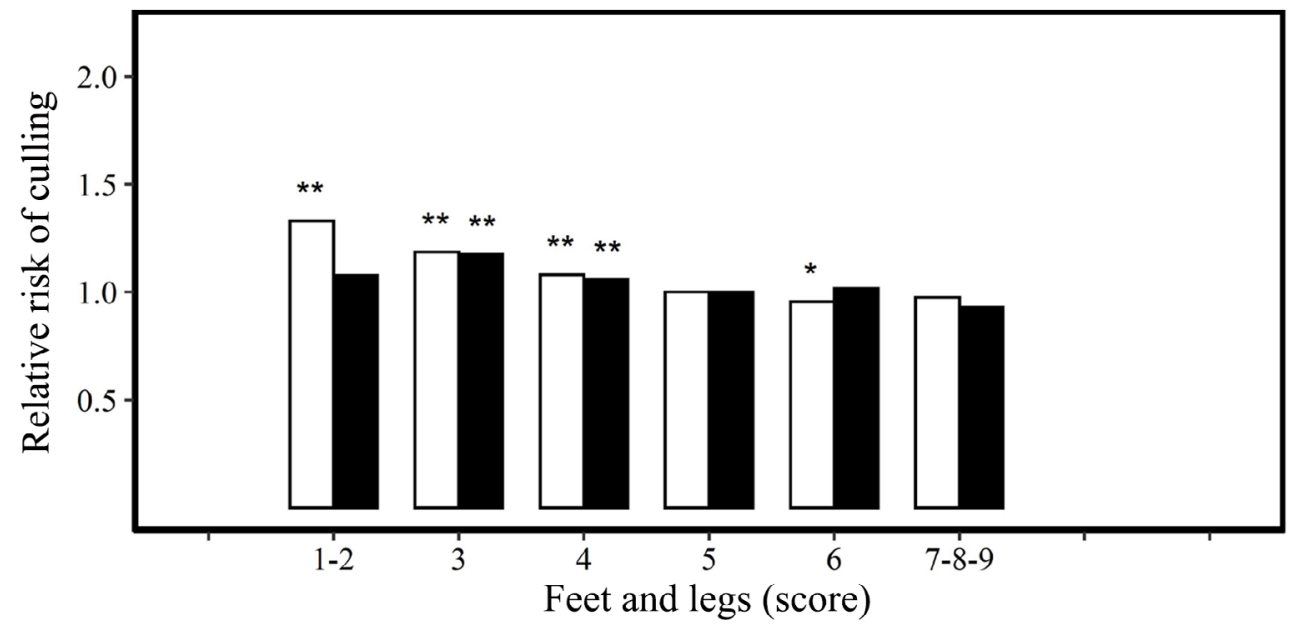

B

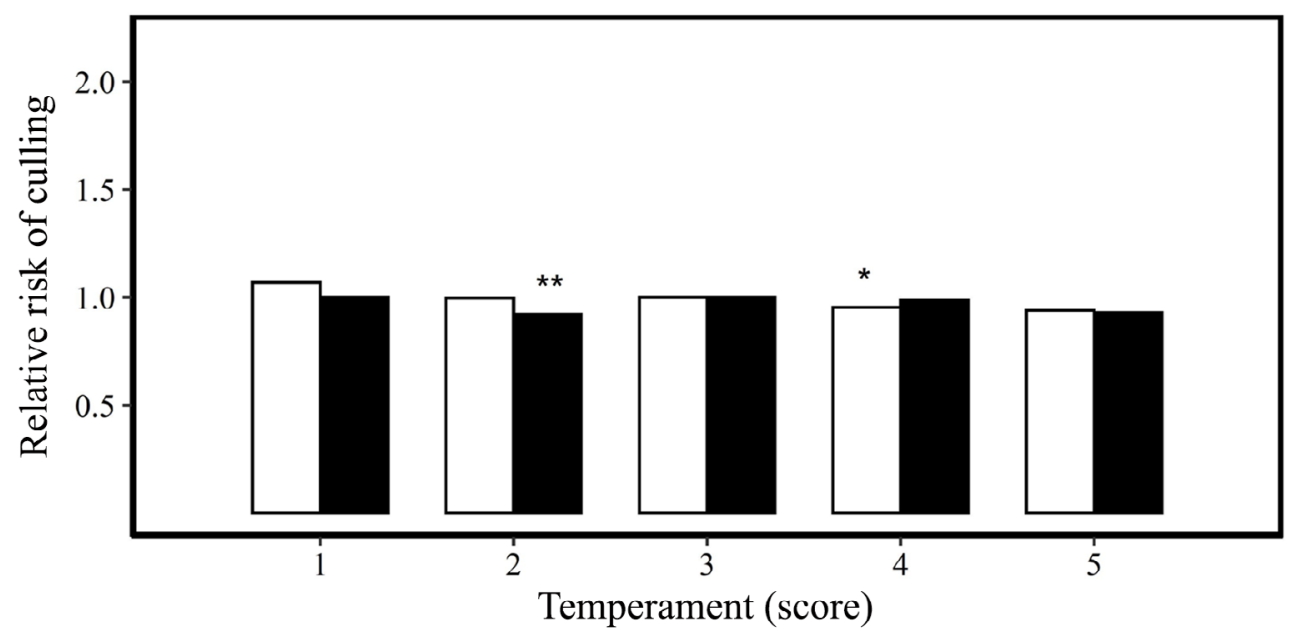

C

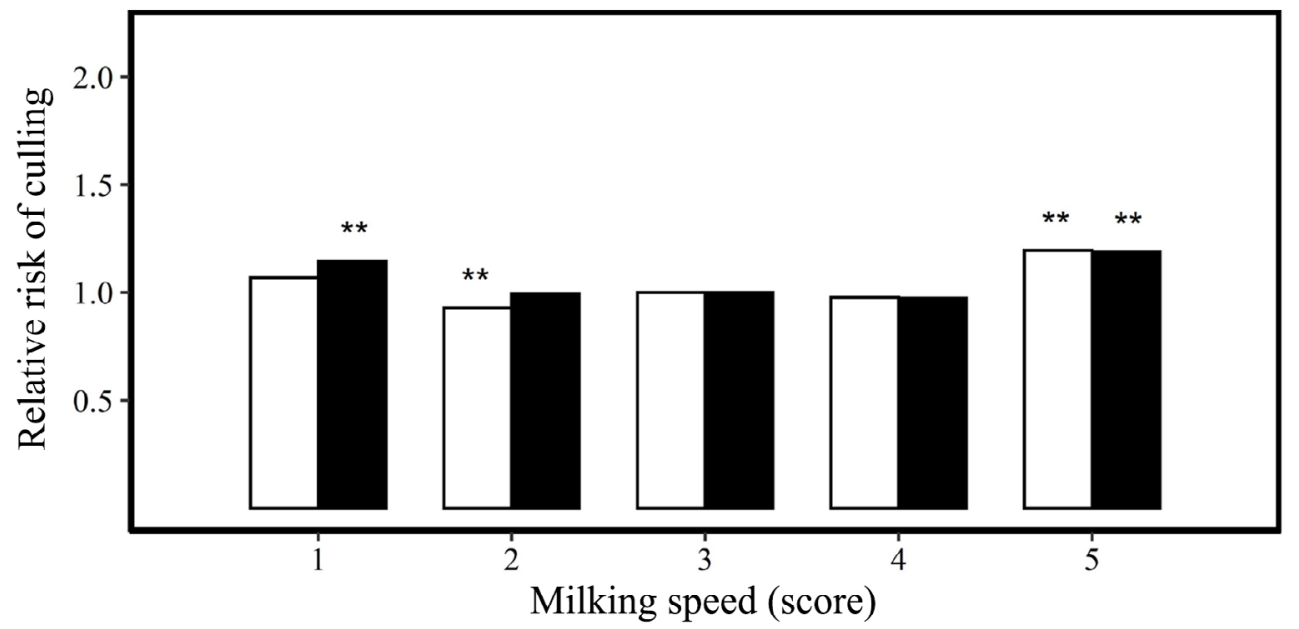

Figure 4. Relative risk of culling for locomotion, temperament, and milking speed associated with true (white bars) and functional (black bars) longevity. Feet and legs score was scored from 1 (poor locomotion) to 9 (easy locomotion); temperament was scored from 1 (very nervous) to 5 (very docile); milking speed was scored from 1 (fast milking) to 5 (slow milking). The reference class for feet and legs is score 5; the reference class for temperament and milking speed is score 3. Significance of the $\chi^{2}$ statistic, testing the difference between risk ratios associated with each trait level and that of the reference class; ${ }^{*} P<0.05 ; * * P<0.01$ 
to the reference class, which is difficult to interpret. A weak influence of TEMP on longevity was also found in the study of Larroque and Ducrocq (2001).

Animals with extreme scores for MSP (MSP $=1$ and MSP $=5$ ) showed a significantly higher risk of being culled than cows in the reference class for both TL and FL (Figure 4C). Farmers are probably less inclined to keep slow-milking cows in the herd because they can disrupt the flow of animals through the milk parlor and they require more labor. Similarly, higher culling of very fast milking cows can be due to their increased risk of having high SCC (Rupp and Boichard, 1999).

When considered across traits, the differences in RR between TL and FL show that once the effect of milk yield on culling has been removed we see that FL is affected by diseases and reproductive problems, factors that are known to reflect resilience (Adriaens et al., 2020). In addition, the strong influence of milk production level on RR suggests that FL is a better indicator of long-term resilience per se as the influence of milk production level on culling is adjusted for. However, TL is also of interest as a proxy as it will include any potential trade-off between resilience and production.

Given their influence on TL and FL, some of the major phenotypes studied here are obvious candidates to improve the accuracy of genetic and genomic evaluations of true or functional longevity in a multiple trait context, expanding what has been implemented in French dairy cattle (Interbull, 2020). Furthermore, the analysis performed in this study can also be applied to evaluate how different environments and different farming conditions (e.g., multibreed herds or organic farming) may affect the factors influencing LPL. In our work, each of the investigated traits was studied distinctly from the others. Hence, future investigations to evaluate, on larger data sets, the potential interaction between traits would be useful to better understand how they influence TL and FL.

\section{CONCLUSIONS}

To identify culling risk factors, which can be prioritized to study and improve resilience in dairy cattle, the present study investigated the influence of several factors related to fertility, morphology, and health status on true or functional longevity. Our analyses revealed that insemination status, CALV, CM, SCC, DA, and UDE have a significant effect on TL and FL. Differences in RR between TL and FL show that milk production often influences the risk of culling for all the aforementioned traits: animals with low production but with good other characteristics still run a high risk of being culled, logically reflecting the strong effect of the economic factors on culling decisions.

\section{ACKNOWLEDGMENTS}

This study was performed as a part of the European Union's Horizon 2020 research and innovation program "Genomic management Tools to Optimise Resilience and Efficiency" (GenTORE), grant agreement no. 727213. The authors gratefully acknowledge the GenoSanté Consortium (France) for providing the data related to diseases used in this study. The authors also thank N. Bareille (Oniris, Nantes, France) for her helpful collaboration. The authors have not stated any conflicts of interest.

\section{REFERENCES}

Adriaens, I., N. C. Friggens, W. Ouweltjes, H. Scott, B. Aernouts, and J. Statham. 2020. Productive life span and resilience rank can be predicted from on-farm first-parity sensor time series but not using a common equation across farms. J. Dairy Sci. 103:7155-7171. https://doi.org/10.3168/jds.2019-17826.

Bar, D., Y. T. Gröhn, G. Bennett, R. N. González, J. A. Hertl, H. F. Schulte, L. W. Tauer, F. L. Welcome, and H. Schukken. 2007. Effect of repeated episodes of generic clinical mastitis on milk yield in dairy cows. J. Dairy Sci. 90:4643-4653. https://doi.org/10 .3168/jds.2007-0145.

Beaudeau, F., V. Ducrocq, C. Fourichon, and H. Seegers. 1995. Effect of disease on length of productive life of French Holstein dairy cows assessed by survival analysis. J. Dairy Sci. 78:103-117. https: //doi.org/10.3168/jds.S0022-0302(95)76621-8.

Beaudeau, F., H. Seegers, V. Ducrocq, C. Fourichon, and N. Bareille. 2000. Effect of health disorders on culling in dairy cows: A review and a critical discussion. Ann. Zootech. 49:293-311. https://doi .org/10.1051/animres:2000102.

Berghof, T. V. L., M. Poppe, and H. A. Mulder. 2019. Opportunities to improve resilience in animal breeding programs. Front. Genet. 9:692. https://doi.org/10.3389/fgene.2018.00692.

Berry, D. P., F. Buckley, P. Dillon, R. D. Evans, M. Rath, and R. F. Veerkamp. 2003. Genetic relationship among body condition score, body weight, milk yield and fertility in dairy cows. J. Dairy Sci. 86:2193-2204. https://doi.org/10.3168/jds.S0022-0302(03)73809 -0 .

Bourrigan, X., S. Mattalia, C. Bouissel, R. Dremaux, M. Dupres, J. J. Evard, X. Gouraud, M. Lega, L. Maurin, B. Schmitt, J. M. Gautier, P. Roussel, and G. Blériot. 2016. Health recording systems: Possible new valorizations of events recorded by farmers. ICAR Tech. Ser. 21:177-182.

Dematawena, C. M. B., and P. J. Berger. 1997. Effect of dystocia on yield, fertility, and cow losses and economic evaluation of dystocia scores for Holstein. J. Dairy Sci. 80:754-761.

Detilleux, J. C., Y. T. Gröhn, S. W. Eicker, and R. L. Quaas. 1997. Effect of left displaced abomasum on test day milk yields of Holstein cows. J. Dairy Sci. 80:121-126. https://doi.org/10.3168/jds.S0022 -0302(97)75919-8.

Ducrocq, V. 1994. Statistical analysis of length of productive life for dairy cows of the Normande breed. J. Dairy Sci. 77:855-866. https: //doi.org/10.3168/jds.S0022-0302(94)77020-X.

Ducrocq, V. 2005. An improved model for the French genetic evaluation of dairy bulls on length of productive life of their daughters. Anim. Sci. 80:249-256. https://doi.org/10.1079/ASC41720249.

Ducrocq, V., R. L. Quaas, E. J. Pollak, and G. Casella. 1988. Length of productive life of dairy cows. 1. Justification of a Weibull model. J. Dairy Sci. 71:3061-3070. https://doi.org/10.3168/jds.S0022 -0302(88)79906-3.

Friggens, N. C., F. Blanc, D. P. Berry, and L. Puillet. 2017. Review: Deciphering animal robustness. A synthesis to facilitate its use in livestock breeding and management. Animal 11:2237-2251. https: //doi.org/10.1017/S175173111700088X. 
Gröhn, Y. T., V. Ducrocq, and J. A. Hertl. 1997. Modeling the effect of a disease on culling: An illustration of the use of time-dependent covariates for survival analysis. J. Dairy Sci. 80:1755-1766. https: //doi.org/10.3168/jds.S0022-0302(97)76109-5.

Gröhn, Y. T., S. W. Eicker, V. Ducrocq, and J. A. Hertl. 1998. Effect of diseases on the culling of Holstein dairy cows in New York State. J. Dairy Sci. 81:966-978. https://doi.org/10.3168/jds.S0022 -0302(98)75657-7.

Interbull. 2020. National Genetic Evaluation Info - France - Combined Longevity. Accessed Oct. 19, 2020. https://interbull.org/ib/ geforms.

Larroque, H., and V. Ducrocq. 2001. Relationship between type and longevity in the Holstein breed. Genet. Sel. Evol. 33:39-59. https: //doi.org/10.1186/1297-9686-33-1-39.

Leclerc, H., I. Croué, R. Vallée, A. Baur, A. Barbat, S. Fritz, M. Philippe, M. Brochard, F. Guillaume, G. Thomas, L. Manciaux, J. B. Davière, L. Voidey, and N. Gaudillière. 2019. French regional genetic collaborative projects to improve welfare and resilience of dairy cows. ICAR Tech. Ser. 24:373-381.

Lee, E. T. 1992. Statistical Methods for Survival Data Analysis. 2nd ed. John Wiley and Sons Inc. https://doi.org/10.1002/0471458546.

López de Maturana, E., E. Ugarte, and O. González-Recio. 2007. Impact of calving ease on functional longevity and herd amortization costs in Basque Holstein using survival analysis. J. Dairy Sci. 90:4451-4457. https://doi.org/10.3168/jds.2006-734.

Mészáros, G., J. Sölkner, and V. Ducrocq. 2013. The Survival Kit: Software to analyze survival data including possibly correlated random effects. Comput. Programs Biomed. 110:503-510. https:// doi.org/10.1016/j.cmpb.2013.01.010.

Neerhof, H. J., P. Madsen, V. P. Ducrocq, A. R. Vollema, J. Jensen, and R. Korsgaard. 2000. Relationships between mastitis and functional longevity in Danish black and white dairy cattle estimated using survival analysis. J. Dairy Sci. 83:1064-1071. https://doi .org/10.3168/jds.S0022-0302(00)74970-8.

Norman, H. D., L. Powell, J. R. Wright, and B. G. Cassell. 1988. Phenotypic and genetic relationship between linear functional type traits and milk yield for five breeds. J. Dairy Sci. 71:1880-1896. https://doi.org/10.3168/jds.S0022-0302(88)79758-1.

Olechnowicz, J., P. Kneblewski, J. M. Jaśkowski, and J. Wlodarek. 2016. Effect of selected factors on longevity in cattle: A review. J. Anim. Plant Sci. 26:1533-1541.

Onyiro, O. M., J. Offer, and S. Brotherstone. 2008. Risk factors and milk yield losses associated with lameness in Holstein-Friesian dairy cattle. Animal 2:1230-1237. https://doi.org/10.1017/ S1751731108002279.

Poppe, M., F. F. Veerkamp, M. L. van Pelt, and H. A. Mulder. 2020. Exploration of variance, autocorrelation, and skewness of deviation from lactation curves as resilience indicators for breeding. J. Dairy Sci. 103:1667-1684. https://doi.org/10.3168/jds.2019-17290.
R Core Team. 2018. R: A language and environment for statistical computing. R Foundation for Statistical Computing. Accessed Oct. 1, 2019. https://www.r-project.org/.

Roxström, A., V. Ducrocq, and E. Strandberg. 2003. Survival analysis of longevity in dairy cattle on a lactation basis. Genet. Sel. Evol. 35:305-318. https://doi.org/10.1186/1297-9686-35-3-305.

Rupp, R., and D. Boichard. 1999. Genetic parameters for clinical mastitis, somatic cell score, production, udder type traits, and milking ease in first lactation Holstein. J. Dairy Sci. 82:2198-2204. https: /doi.org/10.3168/jds.S0022-0302(99)75465-2.

Samoré, A. B., M. P. Schneider, F. Canavesi, A. Bagnato, and A. F. Groen. 2003. Relationship between somatic cell count and functional longevity assessed using survival analysis in Italian HolsteinFriesian cows. Livest. Prod. Sci. 80:211-220. https://doi.org/10 .1016/S0301-6226(02)00185-9.

Schneider, M. del P., E. Strandberg, V. Ducrocq, and A. Roth. 2005. Survival analysis applied to genetic evaluation for female fertility in dairy cattle. J. Dairy Sci. 88:2253-2259. https://doi.org/10 .3168/jds.S0022-0302(05)72901-5.

Sewalem, A., F. Miglior, G. J. Kistemaker, P. Sullivan, and B. J. Van Doormaal. 2008. Relationship between reproduction traits and functional longevity in Canadian dairy cattle. J. Dairy Sci. 91:1660-1668. https://doi.org/10.3168/jds.2007-0178.

Sewalem, A., F. Miglior, G. J. Kistemaker, and B. J. Van Doormaal. 2006. Analysis of the relationship between somatic cell score and functional longevity in Canadian dairy cattle. J. Dairy Sci. 89:3609-3614. https://doi.org/10.3168/jds.S0022-0302(06)72400 $-6$.

VanRaden, P. M., C. M. B. Dematawewa, R. E. Pearson, and M. E Tooker. 2006. Productive life including all lactations and longer lactations with diminishing credits. J. Dairy Sci. 89:3213-3220. https://doi.org/10.3168/jds.S0022-0302(06)72596-6.

Wilson, D. J., R. N. González, J. Hertl, H. F. Schulte, G. J. Bennett, Y. H. Schukken, and Y. T. Gröhn. 2004. Effect of clinical mastitis on the lactation curve: a mixed model estimation using daily milk weights. J. Dairy Sci. 87:2073-2084. https://doi.org/10.3168/jds .S0022-0302(04)70025-9.

Zavadilová, L., E. Němcová, and M. Štípková. 2011. Effect of type traits on functional longevity of Czech Holstein cows estimated from a Cox proportional hazards model. J. Dairy Sci. 94:40904099. https://doi.org/10.3168/jds.2010-3684.

\section{ORCIDS}

R. Rostellato $\odot$ https://orcid.org/0000-0001-5538-3377

H. Leclerc ๑ https://orcid.org/0000-0002-2103-2234

D. Boichard @ https://orcid.org/0000-0003-0361-2961 